\title{
Learning Resources Based on Tolerance Values in the Local Art Work: Case Study in Jepara's Sculpture
}

\author{
Triyanto Triyanto $^{1}$, Eko Sugiarto ${ }^{2}$, Mujiyono Mujiyono $^{3}$ \\ \{triyanto@mail.unnes.ac.id'1 , ekosugiarto@mail.unnes.ac.id², mujiyonosenirupa@mail.unnes.ac.id ${ }^{3}$ \} \\ Visual Art Department, Language and Art Faculty, Universitas Negeri Semarang
}

\begin{abstract}
This research explains of learning resources based on tolerance values in the local art work, in Jepara's carving of Central Java. The Jepara's carving is a representation of the Indonesia's local art containing multicultural values. A qualitative method was applied in this research. The data were collected through observation to local art locations, interviews with craftsmen and documentation studies on the sculptural works. The data were then analyzed through a reduction procedure, presentation, and interactive verification. The results of the research showed that the realization of Jepara's sculptural works exposed the varieties of art forms and provided features on various typical styles, themes, techniques, ornaments, forms, and sizes. Open and tolerative cultural attitude and behavior were shown in the Jepara's art works. Values for this multiethnic tolerance have shown significant potencies as art learning resources. As a value, multiethnic tolerance can be transferred to the classroom learning environment
\end{abstract}

Keywords: arts education; multicultural; tolerance

\section{Introduction}

The attitude and behavior of understanding and respecting differences are inevitable. Let alone if this happens in a country where citizens are multiethnic and multicultural in nature $[1,2]$. This inevitability is urgently required by complex citizens in such a community. These multicultural values can be introduced to citizens in community through educational resources in a wider sense. The introduction of actions through education is viewed as the best solution of form for multicultural education since it is based on the dreams for social justice and equity. Through the multicultural education, the students will be aware of their own cultural roots and as social creatures they are more sensitive to other cultures ranging from local, national, to global levels. The values of multiethnic tolerance held in formal education have proved to contribute to the same chances and equity to students from different ethnical groups $[2,3]$

As the crafts center, the development of carving varieties in Jepara continues up to the recent time. In the course of its development, the craftsmen and business people are developing forms, styles, and motives as requested by the market [4]. The intensive meetings between the craftsmen and buyers from outside Jepara, have given some consequences to the forms of Jepara's carving which have shown some varieties of their designs. For the sustainability of the carving business, most of the craftsmen with their creativity and philosophical flexibility, accommodate the choice to modify local forms to adapt them with the newer stylistic design. 
The craftsmen's flexibility to create new work designs cannot be separated from the structural characteristics of Jepara's people. It is based on the historical facts that the craftsmen are parts of the Jepara's society originating from coastal areas [4-6]. The coastal characters have eased the initial process of stylistic acculturation of Jepara's sculptures combining the Javanese-Indies, Islamic and Chinese cultures that have been flexibly running to the formation of traditional Jepara's sculptures. The Jepara's carving is developing its form when acculturated with the cultures of western design, i.e. Europe [7-10]

This research aims to find out three different aspects: (1) varieties of sculptures in Mulyoharjo village, Jepara; (2) attitude and behavior of the craftsmen to work; and (3) multicultural values showing their potencies as the educational resources in the community. The findings of this research are expected to show significant contribution in developing the multicultural educational values through art resources created by the community. Through the use of qualitative method, the data derived from the research together with their analyses are directed to discuss and answer the research problems.

Therefore, in the context of arts education, Jepara's carving as the Indonesian local art profile has shown significant potencies to be a learning resource to promote values of cross ethnical tolerance through arts education. UNESCO has stated that the arts education in the 21 st century has been able to accommodate awareness of cultural diversity in addition to strengthen the development of capacity for students' creativity [15].

\section{Methods}

\subsection{Focus of Study}

This research covers: (1) the realization of Jepara's carving in term of variety of forms; (2) the attitude and behavior of the craftsmen, as members of community in coastal cultures, in producing their art works; and (3) values in multiethnic tolerance in their art works as learning resources in the multicultural arts education.

\subsection{Research Design}

This research applied a qualitative approach. The research was a case study applied to craftsmen in Jepara Regency, Central Java Province, Indonesia. Since Indies-Dutch period in the fourteenth century, Jepara Regency has been known as the centre for carving. Jepara Located in the strategic trading route of the north coastal area of Java Island, Jepara has represented the values of multiculturalism.

\subsection{Data Collection}

The subjects of the research, among others, were craftsmen, teachers, and Jepara's public figures showing their knowledge and understanding of Jepara's coastal cultures in general and knowing its carving in particular. The data were collected through site observation, interviews, and some relevant documentation. The research data were triangulated in term of sources to achieve trustworthiness. 


\subsection{Data Analysis}

The analysis was done through reduction process, presentation, and data verification using an interactive cycle analysis model. [11]

\section{The Existence of Carving Varieties from Mulyoharjo Jepara}

The carving products from Mulyoharjo village, Jepara are generally made of teak wood, mahogany, rain tree, and suar wood. Various products resulted from the carving are classified into two categories, primary and supporting carving works. The primary carving works consist of sculptures and relief, while the supporting carving works contain carving decoration varieties, i.e. calligraphy, daily needs which include decorative box, shelves for the Quran, table lamp, cigarette ash, wall hangings, frames, mirror glass, and the other small souvenirs. The sculptures can be classified into three different categories: abstract, semi-abstract, and realistic and these are exposed in three distinctive features: classical, modern, and postmodern.

The characteristics of Jepara's carving products are more likely directed to identify subjects, styles, forms, techniques, and philosophy which follow the aesthetical trends of market. These characteristics of the carvings reflect the craftsmen's openness and tolerance to respect and accept the market orders. Chamin states that the features of carving will show the expression of their values as craftsmen originating from a coastal community [12].
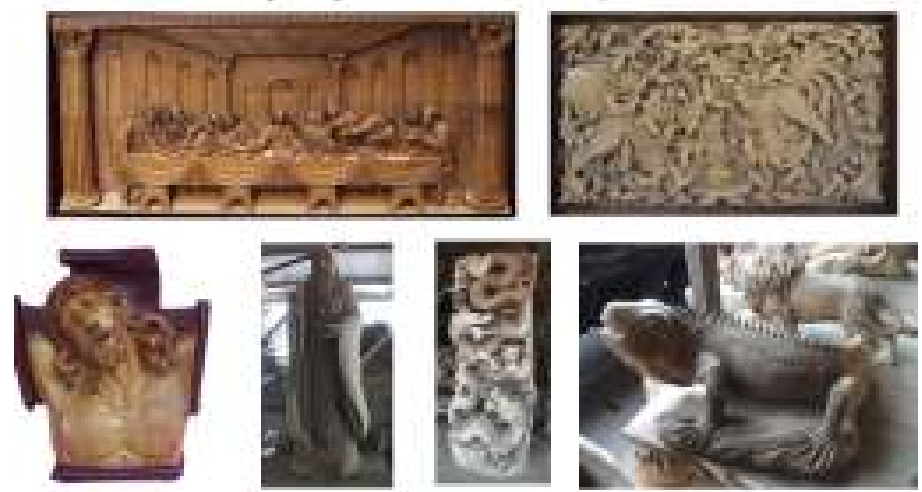

Fig. 1. The existence of The Last Supper, Flora and Fauna, Sculptures of Jesus Christ, Chinese Mithology, and Dragon, show the characteristics of Jepara's craftmen to welcome and accommodate varieties of works from different forms and themes.

\subsection{Attitude and Behavior of Craftsmen in the Creation of Carving Works}

Viewed from the aspects of cultures and geography, Jepara's people living in a coastal area are dominantly good moslems [13]. They are moslems who are good in their prayers, but they are flexible, open, tolerant, egalitarian, adaptive, and accommodative to welcome different things coming from outside [14]. These attitude and behavior become characteristics and guidance in undertaking their activities in the community's life. These include their economic activities in producing the carving works. 
The environmental influence which is characterized by coastal cultures have encouraged the craftsmen in Jepara to result in various cravings as requested by the market ranging from styles, themes, techniques, forms, to sizes [4]. Although the craftsmen are culturally citizens of the community who are obedient to pray in their Islamic belief, however, they can show their professionalism in accepting and creating their carvings which are not relevant with their religious faith. They can separate their religious activities from their professionalism. For instance, the craftsmen are moslems, however, they are open and available to make nonislamic religious and cultural symbols in their works. The sculpture and relief describing the Jesus Christ, The Virgin Mary, Princess Kwan Im, Chinese Dragon, the relief of The Last Supper are some of the exposed examples (see: examples of photos in Fig.1). The samples of works can be viewed as the representation of an open and tolerative attitude and behavior to accept and respect differences.

\subsection{Potencies of Multiethnic Tolerant Values in Jepara's Carving Works as Multicultural Education Learning Resources}

The art learning resources are not actually limited to books, but they can be in forms of data, human, artefact, and certain environment which can also be used by students in their learning. In this position, the craftsmen's environmental conditions, i.e. physical and sociocultural conditions, will play role as their learning resources providing information for expressive activities and appreciation of art for students at their schools $[15,16]$.

Some of the visual carving varieties produced by craftsmen in Mulyoharjo village, Jepara have described different cultural symbols including non-Islamic teaching which have reflected the existence of multicultural values in their works [18]. The open and tolerative attitude and behavior are the spirit of multicultural education values existing in the works. Mahfud reiterates that the implementation of multicultural education can be considerably successful when the values have been embedded in the students' ways of life through tolerance, no fighting each other, and no conflicts caused by differences of cultures, tribes, and languages [17].

Varieties of carving forms which are not relevant with the craftmen's belief and cultural systems do not reduce their existence as good moslems. In their opinion, carving works will never influence their religious belief as moslems. They even think that through the creation of such works, they earn for their living including needs to run their religious activities. Through their work as craftsmen, they can build good mosques for their prayers, hold meetings for religious studies, even to some of them can go to Mecca for haj.

These have proved that the attitude of being open and tolerance which is reflected from the varieties of carving works resulted by craftsmen from Mulyoharjo village, Jepara is the practice of multicultural values. Their openness and tolerance in serving various forms of orders have given consequences to adapt them with the development of world globalization. Carving as a part of cultures needs a process of innovation, particularly in terms of forms. The culture will always be existing, running, and developing in the framework of fulfilling daily needs and facing challenges of the environment based on the community development $[10,19]$.

The Road Map for Arts Education (UNESCO) indicates that one of the core missions of arts education is to build cultural awareness [15]. This mission actually reiterates the importance of implementing the arts education which is oriented to any efforts to the open, tolerance, understanding and respecting of differences of people's cultures including the aspects of tribes, races, religions, and ethnical groups. In accordance with this idea, cultural 
varieties should be introduced and transmitted to students in schools through arts education in order that they can accept and respect cultural differences of other communities.

At this point, the multicultural values reflected in the varieties of craftsmen's expressions of carving works in Mulyoharjo, Jepara have already shown the actualization of open and tolerate values in facing, understanding, and respecting cultural differences. These values have been relevant to the essence of multicultural education goals which are basically oriented to the efforts of building values of being open and tolerance to result in the formation of attitude and behavior in order to understand and respect cultural differences from one to another [17]. Therefore, it can be emphasized that the multicultural values that have been existing in various expressions of carving works studied in this research have shown the potencies to use as the multicultural education resources.

In the contexts of arts education, the potencies of multicultural values in the craftsmen's carving works in Mulyoharjo, Jepara can be used as learning resources in the form of appreciative activities, for instance by observing, enjoying, appreciating, and justifying the perceptual impressions received by students as the realization of respect to art works as cultural products. Appreciation to art works through presenting the carvings from Mulyoharjo, Jepara, teachers can introduce, show, and explain the multicultural values existing in the art works to build attitude and cultural awareness in order that the students develop their open and tolerative attitude and behavior in accepting and respecting other cultural differences without forgetting the awareness of their own roots of local cultures.

In the learning processes, the teachers may apply classical, group, or individual approaches through the implementation of question and answer sessions, discussion, and presentation. At this initial stage, the students are introduced to varieties of carving works and their aesthetical values completed by details of multicultural values. Through question and answer sessions and discussion, the students are then given assignments to deeply analyze their understanding to what have been given by the teacher. The result of their understanding should be written in essays and series of essays that should then be presented to their friends in front of the class. In the presentation process the teacher opens the chance for question and answer sessions and discussion to get some comments, inputs, and evaluation from different individuals.

The implication of local art potencies with values of the multiethnic tolerance can be used as references for arts education in schools. Then, the most important point in the context of learning design for arts education is the utilization of learning resources from the local arts through the understanding of parents, people in society, and teachers as the determinant components. The determining factors to consider the environmental potencies to be used as learning resources are: (1) local arts environment (natural-physics and socio-cultures), (2) integrative needs, (3) aesthetic competencies of students, and (4) learning system [16].

\section{Conclusion}

Based on the findings of research and discussion, the conclusions are drawn as follows. First, the realization of Jepara's carving shows the existence of plural or verieties of forms, various typical styles, techniques, carvings, forms, and sizes. Second, the attitude of being open and tolerance can be the bases for the craftsmen in creating their carving works. Third, symbolically, the verieties of expressions of the carving forms in Mulyoharjo, Jepara are reflected from multicultural values showing potencies as multicultural education resources. In 
the context of arts education in school settings, the implementation of potencies can be given in the forms of art appreciation learning. Based on the research findings, it can be shared that the multicultural values that have been existing in the local art forms can be organized as multicultural education resources in general and arts education in particular. For the arts education practitioners, these research findings can be used as inspirative resources in developing multicultural arts education in their own regions through the use of local cultural resources 


\section{References}

[1] Aydin, "A literature-based approaches on multicultural education," Anthropologist, vol. 16, pp. 31-44, 2013.

[2] C. A. Banks, "Equity pedagogy: An essential component of multicultural education," Theory Pract., vol. 34, pp. 152-158, 1995.

[3] Tarman, I. and Tarman, B., "Developing Effective Multicultural Practices: A Case Study of Exploring a Teacher's Understanding and Practices" In: The Journal of International Social Research, 4(17), pp. 578-598, (2011).

[4] Triyanto. Seni ukir belakang gunung desa Mulyoharjo: Varian dalam khazanah tradisi budaya seni ukir di Jepara. Laporan Penelitian Dasar. Jurusan Seni Rupa, Fakultas Bahasa dan Seni, Universitas Negeri Semarang, (2012).

[5] Banks, J. and Banks, C.A. McGee (Eds). Multicultural education: Issues and perspective. 7th ed. USA: John Wiley \& Son, (2010).

[6] Sunaryo, A., "Nirmana" hand-out perkuliahan. Semarang: Jurusan Seni Rupa FBS Universitas Negeri Semarang, (2003).

[7] Gustami, Seni kerajinan mebel ukir Jepara: Kajian estetika melalui pendekatan multidisiplin, Kanisius, Yogyakarta, (2000).

[8] Graham, M.A. "The power of art in multicultural education: The international stories project". In Multicultural Perspectives. 11(3), pp. 155-161, (2009).

[9] Caruso, H.Y.C. "Art as a political act: Expression of cultural identity, self-identity, and gender by Suk Nam Yun and Yong Soon Min”. In The Journal of Aesthetic Education. 39 (3), pp. 71-87, (2005).

[10] Rohidi, T.R. Kesenian dalam pendekatan kebudayaan, STISI, Bandung, (2000).

[11] Miles, M.B. and Huberman, A.M., Analisis data kualitatif. Terjemahan : T.R. Rohidi, U.I. Press, Jakarta, (1992).

[12] Chamim, A.I. and Baidhawy, Z. (eds.), Purifikasi dan Reproduksi Budaya di Pantai Utara Jawa. Kartasura: Pusat Studi Budaya dan Perubahan Sosial, Universitas Muhammadiyah Surakarta, (2003).

[13] Koentjaraningrat, Kebudayaan Jawa, PN Balai Pustaka, Jakarta, (1984).

[14] Thohir, M., Wacana masyarakat dan kebudayaan Jawa pesisir, Bendera, Semarang, (1999)

[15] UNESCO, "Road map for arts education". In The world conference on art education: Building creative capacities for the 21 st century. Lisbon, Portugal, 6-9 March 2006.

[16] Sugiarto, E., "Kearifan ekologis sebagai sumber belajar seni rupa: Kajian ekologi-seni di wilayah pesisir Semarang", Jurnal Imajinasi. 11(2), pp. 135-142, (2017).

[17] Mahfud, C. Pendidikan multikultural, Pustaka Pelajar, Yogyakarta, (2009).

[18] Takari, M. "Nilai-nilai multikultural dalam kesenian masyarakat kota Medan". Retrieved on 8 August 2018 from http://www.etnomusikolo giusu.com/ uploads/ 1/8/0/0/1800340/ senimultikultur medan.pdf, (2010).

[19] Suparlan, P. "Manusia, kebudayaan, dan lingkungannya: Perspektif antropologi“, Manusia dalam keserasian lingkungan, Lembaga Penerbit Fakultas Ekonomi Universitas Indonesia, Jakarta (1983). 